\title{
Effects of land-use changes on woody species distribution and above- ground carbon storage of forest-coffee systems
}

\author{
Getachew Tadesse *, Erika Zavaleta, Carol Shennan \\ University of California, 1156 High St., Santa Cruz, 95064 CA, USA
}

\section{A R T I C L E I N F O}

\section{Article history:}

Received 22 January 2014

Received in revised form 6 July 2014

Accepted 12 July 2014

Available online xxx

\section{Keywords:}

Carbon biomass

Coffee forests

Fragmentation

Local wood preferences

Wood density

\begin{abstract}
A B S T R A C T
As deforestation and fragmentation continue in tropical regions with high human use and disturbance of natural habitats, production landscapes such as agroforests and plantations may provide some forestbased services depending on tree selection, agroforest management and intensification. This is typical to southwest Ethiopia with strong human-dependence on forest biodiversity and ecosystem services. We examined the effects of land-use changes and fragmentation on woody species distribution and the relative importance of forest fragments and coffee farms in wood use and carbon storage. We sampled heartwood from 71 woody species in three land use types: natural forest fragments, smallholder semiforest coffee farms and state-owned coffee plantations. We calculated wood density as an oven-dry biomass per fresh volume of heartwood core samples, and above-ground carbon biomass using allometric methods. We found that average wood density values were not correlated with fragment size. Mean wood density of species in forests was greater than in state-owned plantations. The two coffee systems can store 50-62\% of the above-ground carbon biomass found in forests, indicating the need to incorporate coffee farms and forest remnants in carbon incentive, or climate mitigation and adaptation programs. To correlate species wood density with local wood preferences, we interviewed focus groups and households about the use-values of 51 farmer-appreciated species. There was a strong correlation between wood density and local wood-values signifying the concordance of species functional traits and ecosystem service values. Our results indicate the need to integrate functional traits and local ecosystem service uses in climate adaptation and mitigation by incorporating coffee agroforests with the conservation of natural forest remnants.
\end{abstract}

(c) 2014 Elsevier B.V. All rights reserved.

\section{Introduction}

If natural ecosystems continue to decline, human-dominated landscapes can play a vital role in maintaining biodiversity (Chazdon et al., 2009; Gardner et al., 2009) and ecosystem services (Schroth et al., 2004). Since much of tropical biodiversity is found outside protected areas (Chazdon et al., 2009), we need to incorporate production landscapes and ecosystem services into conservation programs. The capacity of production landscapes to provide ecosystem services depends on management and disturbance that affects the abundance and distribution of service providing species (Jose, 2009). Woody species distribution in human-dominated forests and agroforests varies as a function of species traits that are desirable for human use, and that are vulnerable to disturbance and fragmentation.

\footnotetext{
* Corresponding author. Tel.: +1 2064898731 .

E-mail address: gettades@gmail.com (G. Tadesse).
}

Wood density, the specific gravity of a wood important is for support and strength. It is one of the functional traits that are affected by fragmentation and disturbance (Carreno-Rocabado et al., 2012). Wood density is also related to wood provisioning and carbon storage (Cornelissen et al., 2003; Saranpaa, 2003; Chave et al., 2009). It affects the weight, strength, flammability, workability, and resistance to decay and termites of a wood and thus the use-value of wood for local people (see FAO, 2011).

In order to meet conservation and livelihood needs, bundling local ecosystem services with global values of biodiversity such as carbon storage and climate mitigation will be important. For this, studies that examine the effects of anthropogenic disturbance on ecosystem services and the complementary roles of production landscapes in local and global-scale provisioning and regulating services are essential. This study examines the effects of fragmentation and forest conversion, into agroforests, on woody species and associated ecosystem services and the role of production landscapes such as coffee agroforests in providing wood related ecosystem services. 
1.1. Effects of fragmentation and human filters on woody species and wood-related services

Fragmentation in this study refers to the conversion of a previously continuous forest into smaller forest patches isolated from each other by non-forested lands (see Fahrig, 2003) such as coffee farms, crop fields, plantations and settlements. Fragmentation and disturbance can affect woody species distribution and abundance as a function of their wood density values. Species with low wood density grow faster and are short-lived and less resistant to fire and herbivory than denser-wood species (Swenson and Enquist, 2007; Poorter et al., 2010; Martinez-Carbera, 2011) (Table 1). Alternatively, dense-wooded species or those with high wood density grow slower, and are more resistant to fire and herbivory but more vulnerable to fragmentation and edge effects than light-wooded species (Carreno-Rocabado et al., 2012). Fragmentation replaces dense-wooded and large canopy tree species with fast-growing pioneers that have low wood density (Laurance et al., 1997). Slik et al. (2008) concluded that average wood density in forests is a robust indicator of successional status and can be used as a conservation monitoring tool in tropical rainforests of Southeast Asia.

Forest fragmentation and conversion to agroforests may have implications on two kinds of ecosystem services: wood provisioning at local scales, and carbon stock potential. Wood provisioning services with respect to locally-valued wood qualities are determined by some wood traits influenced by wood density (see Walker, 1993). In managed forests and coffee farms, the quality, composition, and volume of wood people harvest may vary depending on the shade tree species. Coffee agroforests in tropical ecosystems maintain woody species that are used as coffee shade, fuel-wood, material culture, construction materials, and carbon biomass (Leakey et al., 2005; Rice, 2008; Jose, 2009; Tadesse et al., 2014a). In particular, southwest Ethiopian agro-ecosystems support millions of local people who largely depend on wood and non-wood resources in their day-to-day life.

Understanding the effects of fragmentation and human filters is important for management and conservation that integrates local needs with the conservation of biodiversity and ecosystem services. Studies that examined the effects of fragmentation on woody species distribution and associated ecosystem services in relation to wood density and carbon biomass are very scanty in southwest Ethiopia. Here we asked whether woody species distribution is affected by fragmentation with respect to its differential effects on dense and lighter-wooded species.

We hypothesize that dense-wooded species decline when forests are converted into agricultural landscapes partly due to intrinsic vulnerability of such species to disturbance, and due to human preferences for fast-growing and light-wooded species in managed landscapes, or human filters. Here, we define human

Table 1

Adaptive significance of species with low and high wood density with respect to growth, survival, defense, and resistance to fragmentation and disturbance (Source: Chave et al., 2005; Wright et al., 2007; Poorter et al., 2010; Martinez-Carbera, 2011; Carreno-Rocabado et al., 2012)

\begin{tabular}{lll}
\hline Adaptive significance & Wood density & \\
& Low & High \\
\hline Growth rate & Fast & Slow \\
Size (height and DBH) & Large & Small \\
Crown size & Wider/deeper & Narrower \\
Succession stage & Early & Later \\
Survivorship & Poor & Long-lived \\
Resistance to herbivore, pathogens and fire & Low & High \\
Resistance to fragmentation and disturbance & High & Low \\
Effects of human filters & Varies & Varies \\
\hline
\end{tabular}

filters as human-mediated woody community assembly that is determined by human preference and realized through planting, encouragement and protection of woody species for their ecosystem services. Human filters may also lead to community disassembly via over-harvesting and logging of species in agroforests and forest fragments. To understand human-induced effects on woody species with respect to wood density, we compared variations in average wood density values of species assemblages between natural forests and coffee farms.

\subsection{Aboveground carbon biomass and prospects for climate mitigation}

Carbon storage is another ecosystem service provided by woody species and affected by land-use changes and fragmentation. About $50 \%$ of above-ground living biomass is made up of carbon in forests and agroforests (Clark et al., 2001), and approximately $20 \%$ of global greenhouse gas emissions are from forest degradation and forest conversion to agricultural landscapes (Denman et al., 2007).

Agroforests are agricultural areas with $>10 \%$ tree cover, and they account for $46 \%$ of the agricultural area covering about a billion hectares (Zomer et al., 2009). Although carbon biomass potential of agroforests vary depending on species composition and management, globally they sequester about $1.9 \mathrm{Pg}$ (1.9 billion tons) of above-and below-ground carbon over 50 years (Albrecht and Kandji 2003; Nair et al., 2009). In some coffee growing regions of Indonesia, shade coffee agroforests, depending on shade tree density and composition, can store up to $75 \%$ of the above-ground carbon stored in the adjacent remnant forests (van Noordwijk et al., 2002; Kessler et al., 2012).

Coffee agroforests have great potential in carbon biomass and climate adaptation (Jose and Bardhan, 2014; Verchot et al., 2007). Estimates on the potential of agroforests in Africa in terms of aboveground carbon biomass range from 1.0 to $18.0 \mathrm{MgCha}^{-1}$ (Nair and Nair, 2014). However, agroforest intensification in the form of reduction in shade tree diversity and density reduces carbon storage capacity (Tscharntke et al., 2005; Robinson et al., 2009; de Paula et al., 2011). Traditional agroforests are being intensified into plantations with reduced shade tree density and diversity in southwest Ethiopia (Tadesse et al., 2014a). Carbon stock potential decreases through frequent logging and tree mortality around forest edges and through the replacement of large canopy trees that store high carbon with fast-growing pioneer trees of smaller size and low wood density and with lianas that sequester much less carbon (Laurance et al., 1997; Laurance et al., 2006). We were interested in how much carbon stock potential is at stake if we lose certain native trees by fragmentation or forest conversion into coffee agroforests in southwest Ethiopia. We estimated the aboveground carbon biomass in coffee farms and adjacent forest fragments using wood density and allometric measurements from living aboveground biomass of woody species.

Woody biodiversity conservation and ecosystem service delivery in traditionally diverse coffee agroforests in southwest Ethiopia will depend on conservation incentive programs such as reducing emissions from deforestation and degradation (REDD ${ }^{+}$) and clean development mechanism (CDM). If $\mathrm{REDD}^{+}$is implemented sustainably, it can effectively promote forest management and agricultural practices that increase tree cover for both climate change mitigation and adaptation globally (IPCC, 2014). This requires estimating the amount of carbon biomass stored in forests and agroforests. This study will provide useful information about implications of carbon sequestration in coffee agroforests of southwest Ethiopia to conservation and the livelihoods of smallscale farmers. We estimated the potential of carbon incentives from such programs based on the carbon retention potential of forests and agroforests in the region. 


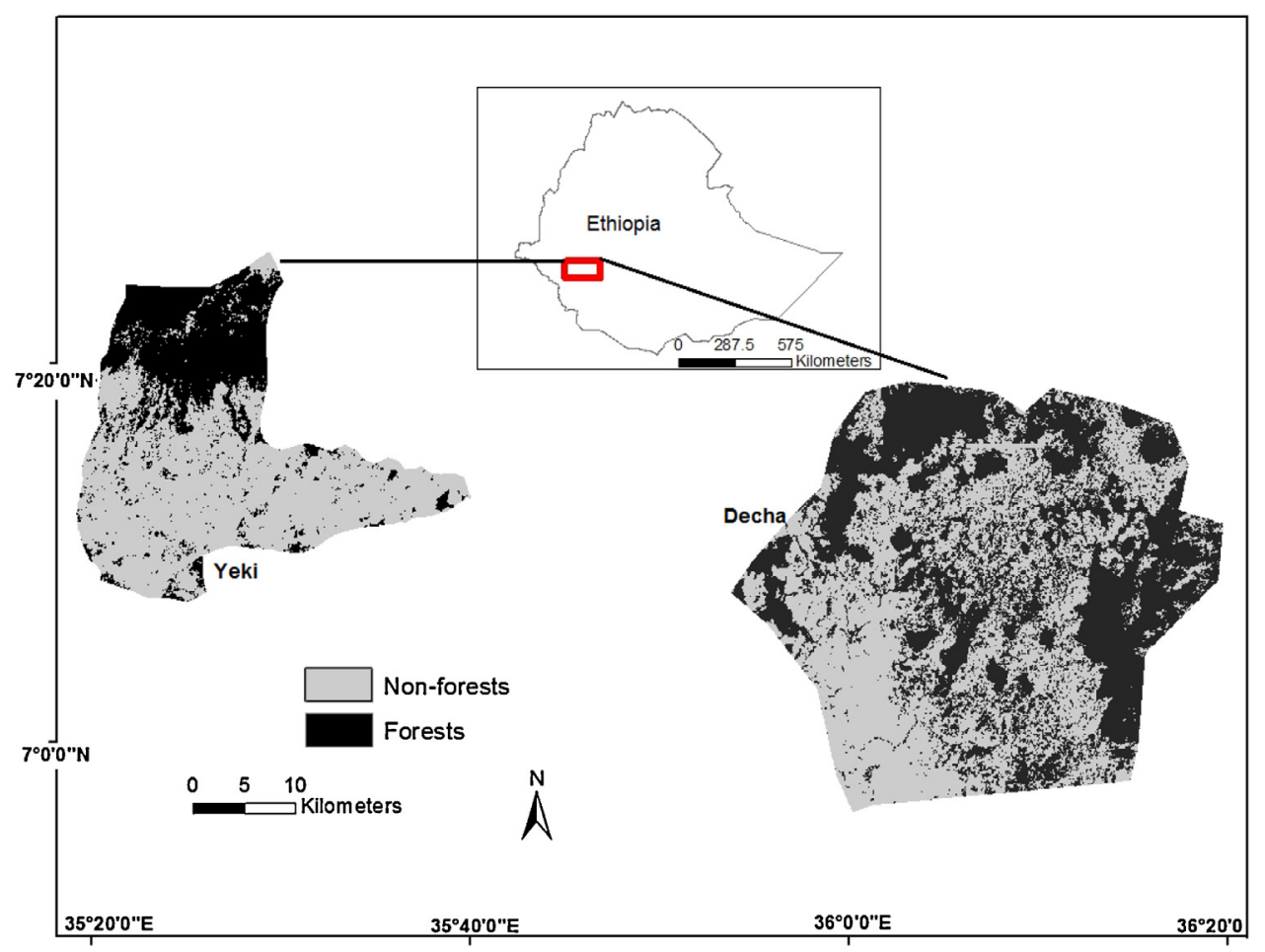

Fig. 1. Map of the study region in southwest Ethiopia with forests (dark-shaded) and non-forests including large-scale coffee plantations, small-scale garden and plantation coffee, and other agricultural and grazing lands (gray-shaded).

\section{Methods}

\subsection{Study area}

This study was conducted in coffee-forest landscape mosaics of two districts in southwest Ethiopia namely, Yeki and Decha (Fig. 1, Table 2a). Southwest Ethiopia is the origin of Arabica coffee, which is cultivated in wild, semi-wild, garden, and plantation production systems (Wiersum et al., 2008). As a major coffee growing region of the nation, this landscape is dominated by coffee plantations and coffee farms, forests and annual crop fields. Yeki landscape is covered by forests (32\%) and plantation and smallholder garden shade coffee (38\%); and our study site in Decha region is mainly covered by forests with wild and semi-wild coffee (39\%). We studied three land-use types, forest fragments, smallholder semiforest/garden coffee and state-owned plantations (Table 2b). State-owned coffee plantations are part of the 17,000 ha semimechanized and large-scale shade coffee systems in the region. Shade trees on these farms are largely native species, although more fast-growing exotic species have been introduced recently. Smallholder farms are coffee agroforests of $\leq 3$ ha that are owned by approximately 15 million subsistence farmers throughout the country (Petit, 1997). Smallholder coffee systems are diverse in production (wild, semi-wild, garden), management, tree choices and intensification levels, and have generally higher shade tree species diversity than state-owned coffee plantations (Tadesse et al., 2014b). There is very limited access to state-coffee plantations for wood products although local people are allowed to cut grasses and fodder (usually weeds) in the plantations following permission by the farm managers. We included stateowned coffee plantations only for carbon stock benefits. Since local people do not have direct access for using wood and non-wood products, the plantations were excluded during informant interviews about woody species found in forests and small-holder coffee farms.

\subsection{Wood sampling}

We studied 71 woody species of 470 randomly selected individuals from $73,20 \mathrm{~m} \times 20 \mathrm{~m}\left(400 \mathrm{~m}^{2}\right)$ plots in 16 fragments; $26,400 \mathrm{~m}^{2}$ plots from 26 smallholder coffee farms; and $25,400 \mathrm{~m}^{2}$ plots from 3 large state-owned coffee farms. The plots used for wood density samples were randomly selected across transects that were established from forest edges (within $300 \mathrm{~m}$ of forest boundaries) to interiors, and across semi-forest, garden and plantation coffee systems. We measured DBH using diameter tape for each woody individual with $\mathrm{DBH} \geq 10 \mathrm{~cm}$. Height were estimated using laser range finders and clinometers. We sampled heartwood density at breast height from 470 randomly selected trees and shrubs of 71 native species (DBH $\geq 10 \mathrm{~cm}$ ) using $2.5 \mathrm{~mm}$ diameter increment borers. We then measured the mass of airdried samples using an electronic balance ( $0.001 \mathrm{~g}$ precision), and the volume indirectly by the volume of water displaced by the core samples at the ecophysiology laboratory of Addis Ababa University,

Table 2a

Biophysical characteristics of the study area in Yeki and Decha districts.

\begin{tabular}{|c|c|c|c|c|c|c|c|}
\hline District & Area $\left(\mathrm{km}^{2}\right)$ & $\begin{array}{l}\text { Slope } \\
\left({ }^{\circ}\right)\end{array}$ & $\begin{array}{l}\text { Elevation } \\
(\mathrm{m})\end{array}$ & $\begin{array}{l}\text { Lat. } \\
\left({ }^{\circ} \mathrm{N}\right)\end{array}$ & $\begin{array}{l}\text { Long. } \\
\left({ }^{\circ} \mathrm{E}\right)\end{array}$ & $\begin{array}{l}\text { MAT } \\
\left({ }^{\circ} \mathrm{C}\right)\end{array}$ & $\mathrm{TRF}(\mathrm{mm})$ \\
\hline Yeki & 604 & $0-48$ & $826-2593$ & 7.2 & 35.3 & 21 & 1400 \\
\hline Decha & 1390 & $0-45$ & $815-2478$ & 6.15 & 36.5 & 18 & 1700 \\
\hline
\end{tabular}


Table 2b

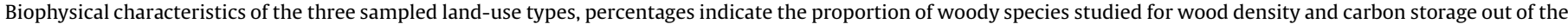
total number of species we found in the corresponding land-use types.

\begin{tabular}{|c|c|c|c|c|c|c|}
\hline LULC ownership & \# of plots & \# of species & Slope $\left(^{\circ}\right)$ & Elevation $(\mathrm{m})$ & Dominant genera & Ownership Management \\
\hline Forests & 73 & $53(39 \%)$ & $0-45$ & $1133-1925$ & Vepris, Olea, Chonanthus, Syzigium, Phoenix, Trilepsium & State-owned,some local access \\
\hline $\begin{array}{l}\text { Smallholder } \\
\text { coffee }\end{array}$ & 25 & $54(60 \%)$ & $0-30$ & $1128-1980$ & Millettia, Albizia, Cordia,Croton, Phoenix, Mimusops & Owned by farmers \\
\hline Coffee plantations & 26 & $37(93 \%)$ & $0-15$ & $1179-1300$ & Cordia, Albizia,Milicia, Pouteria, Antiaris, Trichilia & State-owned,restricted access \\
\hline
\end{tabular}
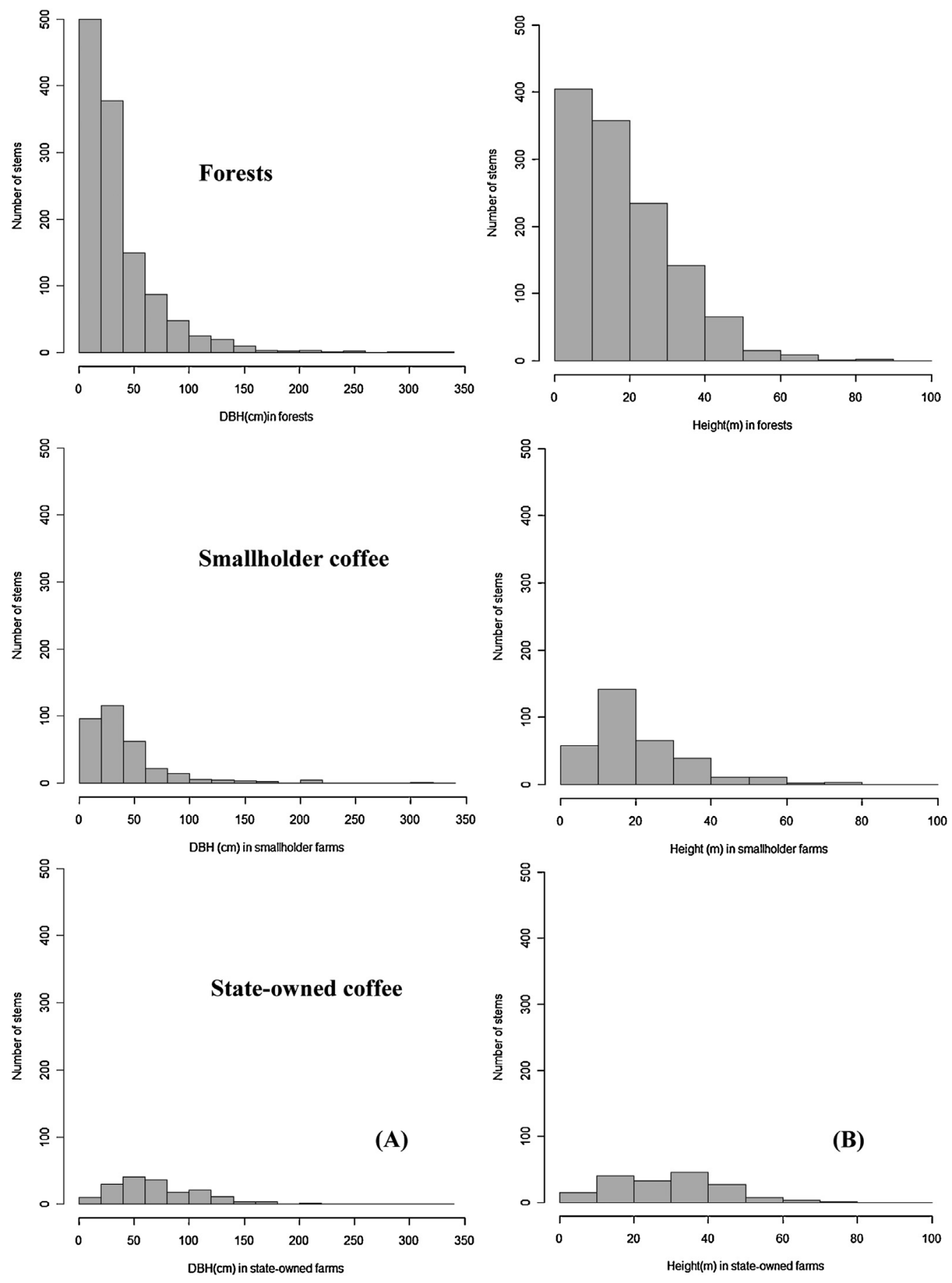

Fig. 2. Size class distribution of trees of woody species in the three land use types with DBH (a) and height (b) on the $x$-axis and number of stems on the $y$-axis. 
Ethiopia. We have calculated the importance value index of woody species we sampled based on relative frequency, relative dominance and relative density of each woody species.

\subsection{Above-ground carbon estimation}

Many studies estimate terrestrial carbon pools from aboveground plant biomass indirectly using non-destructive methods from wood density and stem volume (Chave et al., 2005; Vashum and Jayakumar, 2012). Studies on harvested trees show that wood density is the second-most important parameter that accurately predicts the carbon mass of a tree (Chave et al., 2009), and wood density is less destructive than harvesting and weighing trees (Cornelissen et al., 2003; Ruiz-Jaen and Potvin, 2011). It is the second most important predictor of above-ground carbon stocks in ecosystems (Chave et al., 2005).

We estimated carbon stock of forest fragments and coffee farms indirectly, using stem/stand volume, wood density, and aboveground biomass (AGB in mega grams ha ${ }^{-1}$ ). Stem volume $\left(\mathrm{m}^{3}\right)$ was calculated based on the formula, StemVolume $=\pi \times(\mathrm{DBH} / 2)^{2} \times$ height $\times$ form factor, where DBH and height are in meters and form factor is an allometric relationship between tree height and diameter, which is 0.7 (Cornelissen et al., 2003; Nogueira et al., 2006).

Wood density was calculated as the weight of the sample divided by the volume of wood core samples or the mass of water displaced by its fresh volume. Biomass depends on stem volume and wood density. AGB $\left(\mathrm{Mg} \mathrm{ha}^{-1}\right)$ from woody species $(>10 \mathrm{~cm}$ $\mathrm{DBH}$ ) in natural forests was estimated using the equation $\mathrm{AGB}=0.0509 \times \rho \mathrm{DBH}^{2} \mathrm{H}$ by Chave et al. (2005) for moist tropical forests, where AGB is in mega gram per tree, $\rho$ is the wood density $\left(\mathrm{g} / \mathrm{cm}^{3}\right), \mathrm{DBH}$ is the stem diameter at breast height $(\mathrm{cm})$, and $H$ refers to height of trees in meters. AGB per hectare was then calculated as a product of mean AGB estimates of individual samples in each plot and the density of individuals in a hectare of a forest or a coffee farm. Since the growth architecture of woody species in agroforests varies due to management and habitat conditions, for our coffee agroforests and plantations, we used the allometric equation described by Henry et al. (2009) developed for agroforests in western Kenya as $\mathrm{AGB}=0.051\left(\mathrm{DBH}^{2} \times H\right)^{0.930}$. Finally, based on the assumption that living biomass (tissues) is composed of $50 \%$ carbon, we calculated above-ground carbon stock as $0.5 \times$ AGB for the forests and coffee systems (Chave et al., 2005).

\subsection{Household interviews}

In order to understand how wood density is related to wood value and whether people prefer or use dense-wooded species than light-wooded ones, we convened 10 focus groups and 105 households on woody species use preferences for the following ecosystem services: charcoal/fuel-wood production, beehive support and construction, tools, timber, and termite resistance. Direct matrix ranking (see Martin, 1994) was used to analyze the perceptions of local people (households and focus groups) on the wood qualities of 51 farmer-appreciated species on the following wood qualities or use: termite resistance, construction poles, tools/ furniture, fuel-wood/charcoal production, beehive construction, and support. We explored the correlation between species wood density values and the timber characteristics preferred by local communities.

\subsection{Data analysis}

We tested any correlations between fragment sizes, mean wood density values, aboveground biomass per hectare of the fragments using regression analysis and Pearson's $r$-statistic, and between stem density in forest fragments and above-ground carbon stored by woody species. To compare the mean wood density values, aboveground biomass and carbon stock potential of the three landuse types, we used F-tests and Tukey's post-hoc tests. In order to examine the effect of human filters on wood density distribution across land use types, we correlated species wood density values with their abundance both in coffee farms and across forests. We also used regression analysis to test for any correlations between wood density values of species and local wood preferences for fuel, timber, termite resistance, and construction.

\section{Results}

3.1. Wood density, interactions between land-use changes and human filters on woody species

According to local informants, the most important woody species used for various provisioning services with their usevalues were summarized in Appendix 1. The size class distribution of woody species in this study showed significant variation between forests and coffee plantations (Fig. 2). The number of juvenile individuals $(<10 \mathrm{~cm} \mathrm{DBH})$ in forest fragments was significantly higher than smallholder $(p<0.001)$ and state-owned $(p<0.001)$ coffee farms. Cutting of large-sized trees in smallholder farms and logging of larger trees in forest fragments were more common than the state-owned coffee plantations that are wellprotected (Fig. 2).

We found that wood density varied significantly from species to species $\left(F_{5,70}=5.6, p=0.03\right)$ and from $0.35 \mathrm{~g} / \mathrm{cm}^{3}$ to $1.4 \mathrm{~g} / \mathrm{cm}^{3}$ (mean $\pm \mathrm{SD}, 0.64 \pm 0.18$ ). The wood density distribution of species is provided in Appendix 1. Large tree species ( $>15 \mathrm{~m}$ height) had mean wood density values (mean $=0.64$ ) similar to small tree species of $<15 \mathrm{~m}$ maximum height (mean $=0.61, p=0.9$ ). Within a forest fragment, there were no association between mean wood density of fragments and fragment size $\left(F_{1,16}=1.1, p=0.4\right)$. On average, forest species tend to have denser wood than species found on coffee plantations $(p=0.014)$. However, forest species did not vary from species in smallholder semi-forest coffee systems $(p=0.46)$ (Fig. 3).

According to local informants on the use of woody species for wood products, dense-wooded species were strongly preferred for household use including fuel-wood, charcoal, and construction than other species. Local rankings of preferred wood attributes from our household interviews and focus groups showed that all wood qualities except hive support were significantly correlated with mean wood densities (Table 3 ). The use-values of woody species increased with increasing wood density for timber, fuel,

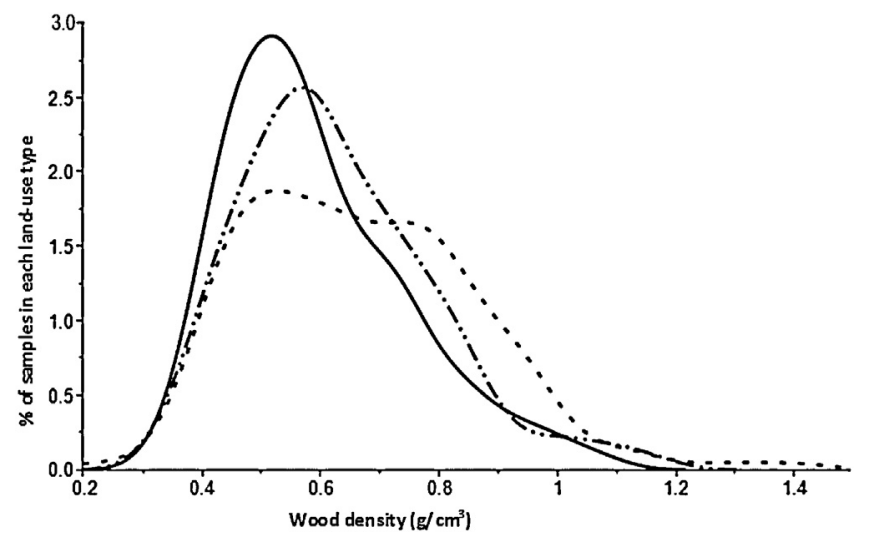

Fig. 3. Distribution of wood density values in forest fragments (solid lines) smallholder semi-forest and garden coffee systems (dotted lines) and state-owned coffee plantations (dotted with dashed lines). 
Table 3

Correlation between farmer preferences for various uses and wood density values of 51 selected woody species, with slope, adjusted $r$-squared and $p$-values

\begin{tabular}{lccc}
\hline Wood quality & slope & $R^{2}$ adj & $p$-value \\
\hline Charcoal making & 4.5 & 0.2 & $<0.001$ \\
Farm tools or furniture & 4.0 & 0.2 & 0.001 \\
Fuel-wood & 4.4 & 0.2 & $<0.001$ \\
Hive construction & -6.1 & 0.4 & $<0.001$ \\
Hive support & -1.1 & -0.005 & 0.4 \\
Termite resistance & 7.2 & 0.4 & $<0.001$ \\
Timber & 4.6 & 0.13 & 0.005 \\
\hline
\end{tabular}

and termite resistance while it was the inverse for hive construction. Generally denser-woods were preferred for fuelwood, timber and termite resistance; however, wood density was not the only criteria for species preferences. Local people, depending on their particular needs, reported that they variably preferred particular types of species based on the straightness of the bole, branching patterns, presence of buttresses, easiness to carve and split, flammability, and availability.

The concordance between mean wood density values of species and their wood use-values by local people confers that some species with very high wood density are overharvested than others. According to our informants, species with higher wood density (Baphia abyssinica, Pouteria spp., Diospyros spp., Olea spp., Morus mesozygia, Manilkara butugi, Pouteria altissima) have high wood use-values, and are overharvested, and should be managed sustainably.

\subsection{Aboveground carbon biomass in forests and coffee agroforests}

As expected, carbon stock capacity increased with increased stem density in the forest fragments $\left(F_{1,16}=5.9, p=0.03\right)$, and with increase in tree size in terms of DBH $\left(F_{1,59}=57.8, p<0.001\right)$ and height $\left(F_{1,59}=25.5, p<0.001\right)$ (Table 4$)$. Forests had higher stem density (281 stems ha ${ }^{-1}$ ) than the two types of coffee farms (Table 4). The density of shade trees maintained in smallholder semi-forest coffee ( 180 stems ha $^{-1}$ ) was almost twice the density on state-owned coffee plantations $\left(96\right.$ stems ha $^{-1}$ ). The per hectare aboveground biomass of forest fragments was not significantly affected by fragment size $\left(F_{1,16}=3.32, p=0.07\right)$. Above-ground carbon biomass varied among the three land-use types $\left(F_{1,312}=4.6\right.$, $p=0.012$ ) with significant variation between smallholder and state-owned plantations ( $p=0.019$ ), and between forest fragments and state-owned plantations. The above-ground carbon stock of forests (mean $\pm \mathrm{SE}=246 \pm 70 \mathrm{tC} \mathrm{ha}^{-1}$ ) and smallholder coffee farms $\left(153 \pm 59 \mathrm{tCha}^{-1}\right)$ was higher than large-scale coffee plantations $\left(123 \pm 12 \mathrm{tC} \mathrm{ha}^{-1}\right)$. The conversion of one-hectare of a forest fragment into traditional semi-forest coffee farms will therefore result in the loss of at least $97 \mathrm{tC}$ above-ground carbon per hectare. Further intensification into large-scale coffee farms such as state-owned ones will result in the loss of more than 30 tC ha $^{-1}$.

\section{Table 4}

Average wood density and above-ground carbon stock of the three land use types, with carbon stock calculated following Chave et al. (2005) ( $\mathrm{FF}=$ forests; $\mathrm{CP}=$ large, state-owned plantations; $\mathrm{SF}=$ small-scale coffee farms; $\rho=$ wood density) different letters a and $b$ represent different significant levels at 95\% confidence intervals using $F$-tests.

\begin{tabular}{llllll}
\hline LULC & DBH $(\mathrm{m})$ & $\begin{array}{l}\text { Volume } \\
\left(\mathrm{m}^{3} \mathrm{ha}^{-1}\right)\end{array}$ & $\begin{array}{l}\text { Stem } \\
\text { density ha }\end{array}$ & $\rho \pm \mathrm{SD}\left(\mathrm{g} \mathrm{cm}^{-3}\right)$ & $\mathrm{tC} \mathrm{ha}^{-1} \pm \mathrm{SD}$ \\
\hline $\mathrm{FF}$ & $0.44^{\mathrm{a}}$ & $1047^{\mathrm{a}}$ & $281^{\mathrm{a}}$ & $0.67 \mathrm{a} \pm 0.19^{\mathrm{a}}$ & $246 \mathrm{a} \pm 70^{\mathrm{a}}$ \\
$\mathrm{SF}$ & $0.51^{\mathrm{ab}}$ & $1061^{\mathrm{a}}$ & $180^{\mathrm{b}}$ & $0.62 \mathrm{ab} \pm 0.16^{\mathrm{ab}}$ & $153 \mathrm{~b} \pm 59^{\mathrm{b}}$ \\
$\mathrm{CP}$ & $0.62^{\mathrm{b}}$ & $936^{\mathrm{a}}$ & $96^{\mathrm{b}}$ & $0.57 \mathrm{~b} \pm 0.15^{\mathrm{b}}$ & $123 \mathrm{c} \pm 12^{\mathrm{c}}$ \\
\hline
\end{tabular}

The aboveground carbon based on conservative carbon emission reduction credits or offset prices from voluntary carbon markets such as the Clean Development Mechanism (CDM) under the Kyoto Protocol, with minimum rate of 4.5 dollars per ton of carbon (Diaz et al., 2011), the total carbon stored (mean \pm SD) in each hectare of forests, smallholder coffee and state-owned coffee plantations would earn about USD $1105 \pm 315$, USD $1036 \pm 266$, and USD $840 \pm 221$ respectively. However, these figures could even be higher based on the carbon financing that widely ranges from USD 0 to 10 .

\section{Discussion}

\subsection{Wood density distribution across forest fragments and coffee farms}

Fragmentation was not correlated with wood density possibly due to the long-term human filters and prolonged disturbance that homogenized woody species composition in most of the forest fragments in southwest Ethiopia. This indicates that most of the forest fragments were at similar successional stages due to the effects of pervasive disturbance (see Silk et al., 2008). However, forests had higher mean wood density than coffee farms since forests contain more old growth and dense-wooded species followed by semi-forest smallholder coffee systems. Species commonly found in coffee farms tend to have lower wood density possibly as a result of farmer selection of fast-growing and lightwooded species that are favorable for coffee shade. When tropical forests are converted into agricultural landscapes, the abundance of large-sized and denser-wooded tree species will be significantly reduced. Large and heavy-wooded tree species $(\rho>0.7)$ tend to be more common (a) in larger forest patches than in smaller ones, and (b) in less disturbed sites than more disturbed ones (Michalski et al., 2007; Silk et al., 2008). Although denser-wooded tree species were more frequent in forests, we found that larger and mature individuals in forests and semi-forest coffee are being logged and over-harvested compared to those in state-owned plantations that are protected from use by local people.

\subsection{Preferences of woody species for various uses by local people}

In addition to coffee shade and other non-timber products and services, people in southwest Ethiopia use forest and agroforest trees for various wood products and fuel on a day-to-day basis. Shade tree species on coffee farms provide various ecosystem services particularly in semi-forest and garden coffee production systems that are managed by smallholder farmers in the study region. Among these were fuel-wood, charcoal, timber, construction of houses and tools, and hanging sites for traditional beehives. Farmers in the region had detailed perceptions about woody species and articulated their preferences for the use of various timber and non-timber wood values.

High density wood from several species was preferred by local people for construction due to minerals and repellent chemicals that prevent wood decomposition and deter termites or inhibit wood decay (Arango et al., 2006). Fuel-wood quality is directly proportional to wood density for some species (Kumar et al., 2010). People in the region preferred higher density wood for charcoal and firewood since the wood burns slower and longer due to high tissue fiber content (see World Agroforestry Center, 2013). Lightwooded species were preferred for making light tools and beehives that can easily be hanged on higher tree branches. People usually prefer mature individuals for certain wood values (e.g., poles, charcoal, termite resistance) due to increased density and mechanical strength as the tree matures. Kuyah et al. (2012) found that wood density increased with tree size and maturity. However, wood density was not the only criterion for local wood 
choices. People also considered the suitability of woody species for various purposes based on the straightness of the bole, the easiness to split and burn, availability, branching structures, and presence of buttresses.

According to our discussions with agricultural departments, several dense-wooded species such as Baphia abyssinica, Pouteria spp., Diospyros abyssinica, Manilkara butugi, Olea capensis, and Morus mesozygia are threatened, among other reasons, due to overharvesting for timber, charcoal, and high quality furniture. The loss of dense-wooded species consequently diminishes most of the provisioning and regulating services such as construction tools and traditional houses, fuel-wood and charcoal, and aboveground carbon biomass. Selective logging of high-value timber species in forests and coffee systems have also negative impact on other nontimber forest products and services as reviewed by Rist et al. (2012) in several tropical countries.

Following the loss of forests and denser-wooded species, local people reported that they maintain some of the highly preferred and dense-wooded tree species such as Albizia gummifera, Diospyros abyssinica, A. schimperiana, Manilkara butugi, Pouteria altissima, P. adolfi-friederici, Milicia excelsa, and Olea capensis in their semi-forest and agroforest coffee systems. Local people reported that they also cope with the loss of dense-wooded native species using alternative strategies such as shifting to other exotic species or man-made materials.

\subsection{Aboveground carbon stocks in forest fragments and coffee systems}

There is wide variation in aboveground carbon biomass of forests perhaps due to varied levels of logging and disturbance. Similarly, the wide-ranging management of smallholder semiforest and garden coffee systems resulted in large variations of aboveground carbon stock in these systems. Coffee agroforests in southwest Ethiopia can store between $50 \%$ and $62 \%$ of the aboveground carbon biomass found from the same area of surrounding forests. This is a higher potential compared to other traditional agroforests in eastern Panama (42\%; Kirby and Potvin, 2007), central Indonesia (49.8\%; Kessler et al., 2012), and comparable to coffee agroforests in Guatemala (Schmitt-Harsh et al., 2012). The forests of southwest Ethiopia store above-ground biomass equivalent to the amount in other tropical montane forests in Africa and globally (Spracklen and Righelato, 2014).

This suggests that Ethiopian coffee agroforests will have greater climate mitigation potential, in addition to providing other ecosystem services, if the density and species richness of shade trees is promoted. However, we observed that local communities in southwest Ethiopia were not aware of carbon storage benefits but understand the role of forests in climate regulation and adaptation. Our results imply that conversion of forests into semiforest coffee systems will not result in excessive losses of aboveground carbon biomass from tree species. Still a hectare of forest patch in our study site have much more carbon stored than both coffee farm types, even without including the biomass stored in the dense understory forest vegetation, belowground carbon, and the carbon biomass from tree saplings and lianas in the forests.

Regeneration in forest fragments was higher than coffee systems (Tadesse et al., 2014b) indicating a higher carbon sequestration potential from forest fragments compared to the coffee systems. Next to forests, smallholder semi-forest and garden coffee systems have more regeneration and hence greater potential for carbon storage. Biodiversity conservation in smallholder shade coffee systems have higher potential for carbon sequestration and climate change mitigation as has been reported by Richard and Mendez (2013). Although AGB and productivity is assumed to increase with species richness (Tilman 1999), there are no consistent relationships between diversity and AGB (Zhang et al., 2012). Additionally, carbon stocks and biodiversity in forests and agroforests are weakly correlated (Kesseler et al., 2012).

About 137 woody species were recorded from forests in the study region, while smallholder semi-forest and garden and stateowned coffee contained 91 and 40 species respectively (Tadesse et al., 2014a). Productivity and carbon stock capacity increases with multi-species plantations than monocultures (Erskine et al., 2006). Ruiz-Jaen et al. (2011) also found that carbon biomass increased with increase in species richness on plantations and with higher proportion of large trees in natural forests. Biomass in smallholder systems may be higher than plantations partly because the former have higher woody species diversity (Tadesse et al., 2014b). The higher proportion of large-sized individuals in state-owned coffee plantations had a contributed to higher carbon stock capacity despite lower shade tree density in the state-owned coffee plantations. However, wood volumes in state-owned farms were higher than forests and smallholder farms because of protection of large state-owned shade trees and reduced competition by thinning in these plantations. The ongoing introduction of fast growing tree species of low wood density and the lack of regeneration in state or large-scale farms will decrease the carbon stock potential of state-owned farms. Although there are limited studies that confirm consistent positive correlation between wood density and carbon biomass (Stegen et al., 2009), a decline in mean wood density will decrease carbon stocks and climate change mitigation.

Forest fragments in the region can store more carbon that can be considered for carbon incentive programs which target reducing carbon emissions. This will encourage large-sized native tree species and promote regeneration of woody species in forest remnants and semi-forest coffee systems which enhance their carbon storage capacity. Through regeneration after recovery from disturbance, light-wooded species will be replaced by later successional and denser woods (Silk et al., 2008). Regeneration increased the AGB in abandoned agricultural lands in the tropics at a rate of $6.2 \mathrm{MgC} \mathrm{ha}^{-1} \mathrm{yr}^{-1}$ during the first 20 years of succession (Silver et al., 2000). The carbon stock potential of many African wet forests increased by $0.63 \mathrm{MgCha}^{-1} \mathrm{yr}^{-1}$ between 1968 and 2007 due to regeneration (Lewis et al., 2009).

Carbon from coffee systems southwest Ethiopia is stored by the diverse shade trees maintained at density of 180 trees ha $^{-1}$ and 281 trees ha ${ }^{-1}$ in state farms and small farms respectively. In addition to the shade trees, carbon can be stored in the perennial coffee plants found at average estimated density of $>2500$ coffee stems ha ${ }^{-1}$ which represents a large volume of wood and aboveground carbon biomass stored from the coffee plants directly. This is especially true for traditional coffee systems where farmers allow old coffee plants to remain in their farms compared to the rapid planting turnovers we observed in the plantations. Thus, there is underestimation of the aboveground carbon biomass in coffee agroforests. Since we overlooked seedlings and saplings, or woody individuals below $10 \mathrm{~cm}$ DBH in the forests in our biomass estimations, our forest biomass findings could also be slightly higher than the figures presented in this study.

Stem density is an important factor in carbon biomass of forests and coffee farms, and carbon biomass increases with an increase in shade tree density in coffee agroforests. The per hectare density of juvenile individuals and small shrubs in forest fragments and semiforest coffee farms in southwest Ethiopia was significantly higher than in state-owned plantations (Tadesse et al., 2014b). Therefore, forests and semi-forest coffee systems will have higher carbon stock potential than plantation coffee due to their higher stem density.

In this study, above-ground carbon biomass per hectare across forest fragments is not affected by fragmentation or patch size 
unless there had been a significant decrease in stem density. This could be because the distribution of species was relatively homogeneous in terms of the stem and wood densities of species. This homogenization is possibly due to a long history of human filters including fragmentation, over-harvesting and logging in both small and large forest patches (Tadesse et al., 2014b). In other regions, fragmentation limits the capacity of forests to retain carbon since it reduces the abundance of large trees (de Paula et al., 2011).

Forest conversion to agricultural lands results in a disproportionate loss of greenhouse gas emissions to the atmosphere (Strassburg et al., 2010). However, agroforestry trees can still store more carbon than field crops or most plantations (tea and palmoil) (Kirby and Potvin, 2007). Exotic plantations of Eucalyptus expanding in the region tend to have lower carbon stocks. According to Hall et al. (2012); regions with expanding exotic plantations experienced decreased carbon stock in contrast to regions with species-rich secondary forests. Exotic species such as Eucalyptus, Grivellea, and Cupressus are becoming common since they are important sources of timber and income. This implies the need to conserve old-growth and denser-wooded species in both forests and coffee agroforests through effective carbon incentive programs.

The aboveground carbon based on conservative carbon emission reduction credits or offset prices from voluntary carbon markets such as the Clean Development Mechanism (CDM) under the Kyoto Protocol, with minimum rate of 4.5 dollars per ton of carbon (Diaz et al., 2011), the total carbon stored in each hectare of forests, smallholder coffee and state-owned coffee plantations would be about $\$ 1107 \pm 315, \$ 689 \pm 266$, and $\$ 554 \pm 54$ respectively. However, these figures could even be higher based on the carbon financing that ranges from $0 \$$ to $10 \$$. IPCC, (2014) described that the use of $\mathrm{RDD}^{+}$will promote climate adaptation benefits in addition to its socio-economic and ecological benefits if agroforests and forests are integrated into conservation.

However, REDD ${ }^{+}$incentives and their effectiveness will depend on and are affected by the use, ownership and management of forest and agroforest resources (Phelps et al., 2010). The effectiveness of REDD ${ }^{+}$programs in terms of improving livelihoods, mitigating climate and conserving biodiversity will also heavily rely on (a) integrating indigenous ecological knowledge and sustainable use of forest and agroforest resources into conservation and management, and (b) safe-guarding the rights of local communities in the use and management of their forest and agroforest resources and (c) promoting land-tenure schemes that secure the long-term ownership of smallholder farmers in order to encourage long-term investment on their land.

\subsection{Conclusion and management implications}

In southwest Ethiopia, the mosaic of remnant forests semi-wild coffee forests, and smallholder coffee agroforests have high potential for provisioning of wood and non-wood services including carbon storage. The fact that strong correlation exists between wood density and local wood values implies the need to integrate functional traits, local use and ecosystem services into conservation planning. Logging, disturbance and human filters are increasing the abundance of low-density and fast growing species in more intensified coffee farms while slow-growing, high-density species still persist in forest fragments. Since high-density species are highly preferred for various uses, prioritizing their conservation would prevent them from logging and local extirpation.

Next to forest fragments, semi-forest, garden and plantation coffee in southwest Ethiopia play vital role in carbon biomass storage and climate regulation. This signifies the need to incorporate them with forests in carbon offset programs. This requires further studies that examine the below-ground or soil carbon stock, and temporary dynamic carbon pools from understory layer and coffee/fruit crops in the forest and coffee farms respectively.

Provisioning (wood and non-wood) and regulating services (carbon biomass) need to be promoted for the sustainability of the forest-coffee mosaics of the region for three major reasons. First, less intensive semi-forest, agroforest and garden coffee systems maintain diverse native species assemblages with higher proportion of the original canopy species. Second, in aggregate, they represent millions of farms encompassing a large expanse of land bigger enough for large-scale conservation incentives and carbon market programs. Third, such incentive programs can stimulate the promotion of biodiversity restoration and ecosystem services that improve the livelihoods of millions of farmers throughout the region.

\section{Acknowledgements}

We acknowledge the Christensen Fund (Grant \# 2012-5908018) and the Department of Environmental Studies at University of California, Santa Cruz for supporting this project. We also thank anonymous reviewers for feedback on this manuscript, E. Zavaleta lab (UCSC) for providing equipment for wood core samples and for providing useful feedback.

\section{Appendix 1.}

Appendix 1. Wood density distribution of woody species from natural forests (NF), smallholder coffee farms (SF) and coffee plantations $(\mathrm{CP})$.

\begin{tabular}{|c|c|c|c|c|c|c|}
\hline Species & $\begin{array}{l}\text { Wood } \\
\text { density } \\
\text { Mean }\end{array}$ & $\begin{array}{l}\text { IVI } \\
\text { SD }\end{array}$ & $\begin{array}{l}\text { Major } \\
\text { local uses } \\
\text { NF }\end{array}$ & SF & $\mathrm{CP}$ & \\
\hline Alangium chinense & 0.4 & 0.05 & 0 & 1 & 0 & Furniture and material culture \\
\hline Albizia grandibracteata & 0.61 & 0.03 & 0 & 3 & 5.8 & Construction, charcoal, bee-forage, coffee shade \\
\hline Albizia gummifera & 0.6 & 0.05 & 1 & 2 & 0 & Construction, charcoal, bee-forage, coffee shade \\
\hline Albizia schimperiana & 0.7 & 0.03 & 1 & 7 & 0 & Fuel-wood, shade, construction \\
\hline Allophyllus abyssinicus & 0.9 & 0.02 & 2 & 1 & 0 & Construction poles \\
\hline Alstonia boonei & 0.36 & 0.15 & 0 & 0 & 8.7 & Construction, beehive hanging \\
\hline Antiaria toxocaria & 0.5 & 0.1 & 0 & 1 & 0 & Construction; material culture \\
\hline Apodytes dimidiata & 0.72 & 0.03 & 1 & 0 & 0.5 & Bee-forage, beehive hanging sites \\
\hline Baphia abyssinica & 1 & 0.28 & 2 & 4 & 1.2 & Construction, fuel-wood, soil fertility \\
\hline Bersama abyssinica & 0.7 & 0.1 & 3 & 1 & 0 & Construction, material culture, tools \\
\hline Blighia unijugata & 0.6 & 0.2 & 0 & 0 & 0 & Fuel-wood \\
\hline Bridelia micrantha & 0.67 & 0.05 & 0 & 0 & 0.5 & Fuel-wood, charcoal \\
\hline Canthium oligocarpum & 0.7 & 0.1 & 2 & 1 & 0 & Construction, fuel-wood \\
\hline Cassipourea malosana & 0.72 & 0.05 & 0 & 0 & 0 & Construction poles \\
\hline
\end{tabular}


(Continued)

\begin{tabular}{|c|c|c|c|c|c|c|}
\hline Species & $\begin{array}{l}\text { Wood } \\
\text { density } \\
\text { Mean }\end{array}$ & $\begin{array}{l}\text { IVI } \\
\text { SD }\end{array}$ & $\begin{array}{l}\text { Major } \\
\text { local uses } \\
\text { NF }\end{array}$ & SF & $\mathrm{CP}$ & \\
\hline Celtis africana & 0.72 & 0.03 & 1 & 2 & 2.4 & Construction, fuel-wood, charcoal \\
\hline Celtis gomphophylla & 0.54 & 0.1 & 0 & 0 & 0 & Construction, fuel-wood, charcoal \\
\hline Celtis phillipensis & 0.86 & 0 & 0 & 2 & 0 & Construction, fuel-wood, charcoal \\
\hline Celtis zinkeri & 0.72 & 0.1 & 0 & 0 & 1 & Construction, fuel-wood, charcoal \\
\hline Chionanthus mildebraedii & 0.9 & 0.02 & 4 & 0 & 0.5 & Fuel-wood, charcoal \\
\hline Cordia africana & 0.54 & 0.05 & 1 & 6 & 1 & Construction, furniture, bee-forage/beehive hanging sites, coffee shade, hanging beehives \\
\hline Croton macrostachyus & 0.54 & 0.04 & 2 & 5 & 0 & Fuel-wood \\
\hline Croton sylvaticus & 0.54 & 0.02 & 0 & 0 & 0.2 & Fuel-wood \\
\hline Cythea manniana & 0.4 & 0.1 & 1 & 0 & 0 & Construction, termite resistant wood \\
\hline Deibollia kilimandscharia & 0.7 & 0.01 & 1 & 1 & 1 & Construction, charcoal \\
\hline Diospyros abyssinica & 0.72 & 0.1 & 1 & 3 & 0 & Construction \\
\hline Dombeya torrida & 0.54 & 0.4 & 1 & 0 & 0 & Fuel-wood \\
\hline Ehretia abyssinica & 0.6 & 0.03 & 1 & 1 & 2.4 & Furniture, farm tools \\
\hline Ekbergia capensis & 0.75 & 0.17 & 1 & 2 & 0 & Bee-forage, best honey, rare mainly in the lowlands, construction, ritual use \\
\hline Elaeodendron buchannani & 0.55 & 0.2 & 1 & 2 & 1.9 & Construction poles, shade \\
\hline Erythrina abyssinica & 0.61 & 0.15 & 0 & 0 & 0 & Fence, soil fertility \\
\hline Eucalyptus camaldulensis & 0.66 & 0 & 0 & 0 & 1.9 & Construction, fuel-wood \\
\hline Euphorbia abyssinica & 0.4 & 0.1 & 0 & 0 & 0 & Beehive construction \\
\hline Fagaropsis angolensis & 0.6 & 0.1 & 1 & 0 & 1.5 & Cattle feed, timber, medicinal \\
\hline Ficus exasperata & 0.45 & 0.12 & 0 & 1 & & Shade, beehive construction and hanging sites \\
\hline Ficus lutea & 0.47 & 0.1 & 0 & 0 & 0 & Shade, beehive construction and hanging sites \\
\hline Ficus ovata & 0.5 & 0.15 & 0 & 1 & 0.5 & Shade, beehive construction and hanging sites \\
\hline Ficus sur & 0.5 & 0.05 & 1 & 1 & 1.9 & Shade, beehive construction and hanging sites \\
\hline Ficus sycamorus & 0.48 & 0.01 & 0 & 0 & 0.5 & Shade, beehive construction and hanging sites \\
\hline Ficus thonningi & 0.47 & 0.07 & 0 & 0 & 0.5 & Fence \\
\hline Ficus vasta & 0.63 & 0.15 & 0 & 0 & 1 & Shade, fodder, beehive construction and hanging sites \\
\hline Flacourtia indica & 0.61 & 0.12 & 0 & 0 & 1 & Fuel-wood, charcoal \\
\hline Greveillia robusta & 0.82 & 0.05 & 0 & 0 & 0 & Fuel-wood, wind break \\
\hline Grewia mollis & 0.76 & 0.1 & 0 & 0 & 0.5 & Fuel-wood, charcoal \\
\hline Grewia trichocarpa & 0.6 & 0.1 & 2 & 0 & & Fuel-wood, charcoal \\
\hline Ilex mitis & 0.65 & 0.1 & 1 & 2 & 0.5 & Bee-forage, bee hives \\
\hline Lannea welwitschi & 0.4 & 0.15 & 0.1 & 1 & 0 & Shade, fuel-wood \\
\hline Lecaniodiscus fraxinifolius & 0.79 & 0.05 & 0 & 0 & 0 & Fuel-wood, construction \\
\hline Lepisanthes senegalensis & 0.38 & 0.1 & 0 & 0 & 0 & Bee-forage, construction, fuel-wood \\
\hline Macaranga capensis & 0.65 & 0.1 & 2 & 2 & 2.4 & Fuel-wood, charcoal \\
\hline Manilkara butugi & 0.92 & 0.07 & 2 & 2 & 1 & Best bee-forage, fruits edible, construction \\
\hline Milicia excelsa & 0.78 & 0.09 & 0 & 1 & 6.8 & Construction, termite resistant \\
\hline Milletia ferruginea & 0.85 & 0.1 & 3 & 9 & 2.9 & Shade, soil fertility, construction, fuel-wood \\
\hline Mimusops kummel & 0.86 & 0.07 & 0 & 1 & 6.8 & Construction, shade \\
\hline Morus mesozygia & 0.58 & 0.1 & 0 & 1 & 1.9 & Construction, termite resistant wood \\
\hline Nuxia congesta & 0.5 & 0 & 2 & 0 & 2.9 & Construction, fuel-wood, bee-forage \\
\hline Ocotea kenyensis & 0.9 & 0.06 & 2 & 0 & 0 & Construction, timber \\
\hline Olea welwitschii & 0.78 & 0.15 & 5 & 0 & 1.9 & Construction, timber \\
\hline Pinus patula & 0.56 & 0.06 & 0 & 0 & 1 & Construction, timber, fuel-wood \\
\hline Pittosporum virdifolium & 0.65 & 0.1 & 0 & 0 & 0 & Construction, fuel-wood \\
\hline Polyscias fulva & 0.55 & 0.04 & 1 & 2 & 0 & Beehive construction and hanging site, shade \\
\hline Pouteria adolfi-friedericci & 0.68 & 0.1 & 1 & 2 & 1.5 & Construction, bee-forage, termite resistant wood \\
\hline Pouteria alnifolia & 0.42 & 0.12 & 1 & 2 & 0 & Construction, fuel-wood, charcoal \\
\hline Pouteria altissima & 0.66 & 0.1 & 1 & 2 & 7.8 & Construction, termite resistant, bee-forage \\
\hline Prunus africana & 0.75 & 0.08 & 1 & 0 & 0 & bark bactericidal treating human and horse infections \\
\hline Rothmania urcelliformis & 0.6 & 0.1 & 2 & 0 & 0 & farm tools, construction, fuel-wood \\
\hline Sapium ellipticum & 0.52 & 0.1 & 1 & 1 & 1.9 & Beehive construction, fuel-wood \\
\hline Schefflera abyssinica & 0.43 & 0.15 & 3 & 1 & 1.9 & Bee-forage, shade, beehive construction \\
\hline Syzigium guineense & 0.7 & 0.12 & 3 & 1 & 0 & Bee forage, construction, fuel-wood, fruits eaten \\
\hline Trelepsium madagascarense & 0.5 & 0.07 & 3 & 1 & 2.4 & Construction, timber, fuel-wood \\
\hline Trema orientalis & 0.6 & 0.1 & 0 & 1 & 0 & Soil fertility \\
\hline Trichillia dregeana & 0.65 & 0.13 & 3 & 1 & 0 & Construction, beehive hanging sites \\
\hline
\end{tabular}

\section{References}

Albrecht, A., Kandji, S.T., 2003. Carbon sequestration in tropical agroforestry systems. Agric. Ecosyst. Environ. 99, 15-27.

Arango, R.A., Green, F., Hintz, K., Lebow, P.K., Miller, R.B., 2006. Natural durability of tropical and native woods against termite damage by Reticulitermes flavipes (Kollar). Int. Biodeter. Biodegr. 57, 146-150.

Carreno-Rocabado, G., Pena-Claros, M., Bongers, F., Alarcon, A., Licona, J., Poorter, L. 2012. Effects of disturbance intensity on species and functional diversity in a tropical forest. J. Ecol. 100, 1453-1463.

Chave, J., Coomes, D., Jansen, S., Lewis, S.L., Swenson, N.G., Zanne, A.E., 2009 Towards a worldwide wood economics spectrum. Ecol. Lett. 12, 351-366.

Chave, J., Andalo, C., Brown, S., Cairns, M.A., Chambers, J.Q., Eamus, D., Folster, H., Fromard, F., Higuchi, N., Kira, T., Lescure, J.P., Nelson, B.W., Ogawa, H., Puig, H., Riéra, B., Yamakura, T., 2005. Tree allometry and improved estimation of carbon stocks and balance in tropical forests. Oecologia 145, 87-99.

Chazdon, R.L., Harvey, C., Komar, O., Griffith, D., Ferguson, B., Martínez-Ramos, M. Morales, H., Nigh, R., Soto-Pinto, L., van Breugel, M., Philpott, S., 2009. Beyond reserves: a research agenda for conserving biodiversity in tropical humanmodified landscapes. Biotropica 41, 142-153.

Clark, D.A., Brown, S., Kicklighter, D., Chambers, J.Q., Thomlinson, J.R., 2001 Measuring net primary production in forests: concepts and field methods. Ecol. Appl. 11, 356-370.

Cornelissen, J.H.C., Lavorel, S., Garnier, E., Díaz, S., Buchmann, N., Gurvich, D.E. 2003. A handbook of protocols for standardized and easy measurement of plant functional traits worldwide. Aust. J. Bot. 51, 335-380.

de Paula, D.M., Costa, A.C.P., Tabarelli, M., 2011. Carbon biomass in a fragmented landscape of Atlantic forest: the role played by edge-affected habitats and emergent trees. Trop. Con. Sci. 4, 349-358.

Diaz, D., Hamilton, K., Johnson, E., 2011. State of the Forest Carbon Markets: From Canopy to Currency. Ecosystem Marketplace, Washington DC.

Denman, K.L., Brasseur, G., Chidthaisong, A., Ciais, P., Cox, P.M., 2007. Couplings between changes in the climate system and biogeochemistry. In: Solomon, S (Ed.), Climate Change 2007: The Physical Science Basis. Contribution of Working Group I to the Fourth Assessment Report of the Intergovernmental Panel on Climate Change. Cambridge, pp. pp663-745. 
Erskine, P.D., Lamb, D., Bristow, M., 2006. Tree species diversity and ecosystem function: can tropical multi-species plantations generate greater productivity? Forest Ecol. Manage. 233, 205-210.

Fahrig, L., 2003. Effects of habitat fragmentation on biodiversity. Annu. Rev. Ecol. Evol. Syst. 34, 487-515.

FAO, 2011. Rural Structures in the Tropics: Design and Development. Food and Agriculture Organization of the United Nations, Rome.

Gardner, T.A., 2009. Prospects for tropical forest biodiversity in a human-modified world. Ecol. Lett. 12, 561-582.

Hall, J.M., Van Holt, T., Daniels, A.E., Balthazar, V., Lambin, E.F., 2012. Trade-offs between tree cover carbon biomass and floristic biodiversity in reforesting landscapes. Landscape Ecol. 27, 1135-1147.

Henry, M., Tittonell, P., Manlay, R., Bernoux, M., Albrecht, A., vanLauwe, B., 2009. Biodiversity, carbon stocks and sequestration potential in aboveground biomass in smallholder farming systems of western Kenya. Agric. Ecosyst. Environ. 129 (1-3), 238-262.

IPCC, 2014. Summary for Policymakers. In: Edenhofer, O., Pichs-Madruga, R., Sokona, Y., Farahani, E., Kadner, S., Seyboth, K., Adler, A., Baum, I., Brunner, S., Eickemeier, P., Kriemann, B., Savolainen, J., Schlömer, S., von Stechow, C., Zwickel, T., Minx, J.C. (Eds.), Climate Change 2014, Mitigation of Climate Change. Contribution of Working Group III to the Fifth Assessment Report of the Intergovernmental Panel on Climate Change. Cambridge University Press, Cambridge, United Kingdom and New York, NY, USA.

Jose, S., 2009. Agroforestry for ecosystem services and environmental benefits: an overview. Agrofor. Syst. 76, 1-10.

Jose, S., Bardhan, S., 2014. Agroforestry for biomass production and carbon sequestration. Agrofor. Syst. 86, 105-111.

Kessler, M., Hertel, D., Jungkunst, H.F., Kluge, J., Abrahamczyk, S., 2012. Can joint carbon and biodiversity management in tropical agroforestry landscapes be optimized? PLoS ONE 7 (10), e47192 doi:http://dx.doi.org/10.1371/journal, pone.0047192.

Kirby, K.R., Potvin, C., 2007. Variation in carbon storage among tree species: implications for the management of a small-scale carbon sink project. Forest Ecol. Manage. 246, 208-221.

Kumar, R., Pandey, K.K., Chandrashekar, N., Mohan, S., 2010. Effect of tree-age on calorific value and other fuel properties of Eucalyptus hybrid.J. For. Res. 21, 514-516.

Kuyah, S., Dietz, J., Muthuri, C., Jamnadass, R., Mwangi, P., Coe, R., Neufeldt, H., 2012. Allometric equations for estimating biomass in agricultural landscapes: I aboveground biomass. Agric. Ecosyst. Environ. 158, 216-224.

Laurance, W.F., Nascimento, H., Laurance, S.G., Andrade, A., Fearnside, P.M., Ribeiro, J., 2006. Rain forest fragmentation and the proliferation of successional trees. Ecology 87, 469-482.

Leakey, R.B., Tchoundjeu, Z., Schreckenberg, K., Shackleton, S.E., Shackleton, C.M., 2005. Agroforestry tree products (AFTPs): targeting poverty reduction and enhanced livelihoods. Int. J. Agric. Sustain. 3, 1-23.

Lewis, S.L., 2009. Increasing carbon storage in intact African tropical forests. Nature 457, $1003-\mathrm{U} 1003$.

Martin, G.J., 1994. Ethnobotany, a Methods Manual. People and Plant Conservation Manuals, vol. 1. Chapman \& Hall, London New York, pp. 268p.

Martinez-Carbera, I., 2011. Integration of vessel traits wood density, and height in angiosperm shrubs and trees. Am. J. Bot. 98, 915-922.

Michalski, M., Nishi, I., Peres, C.A., 2007. Disturbance-mediated drift in tree functional groups in amazonian forest fragments. Biotropica 39, 691-701.

Schmitt-Harsh, M., Evans, T.P., Castellanos, E., Randolph, J.C., 2012. Carbon stocks in coffee agroforests and mixed dry tropical forests in the western highlands of Guatemala. Agrofor. Sys. 86 (2), 141-157.

Nair, P.K.R., Nair, N.D., 2014. 'Solid-fluid-gas': the state of knowledge on carbonsequestration potential of agroforestry systems in Africa. Curr. Opin. Environ. Sustain. 6, 22-27.

Nair, P.K.R., Kumar, B.M., Nair, V.D., 2009. Agroforestry as a strategy for carbon sequestration. J. Plant Nutr. Soil Sc. 172, 10-23.

Nogueira, E.M., Nelson, B.W., Fearnside, P.M., 2006. Volume and biomass of trees in central Amazonia: influence of irregularly shaped and hollow trunks. Forest Ecol. Manage. 227, 14-21.

Phelps, J., Webb, E.L., Agrawaal, A., 2010. Does REDD ${ }^{+}$threaten to recentralize forest governance. Science 328, 312-313.

Poorter, L., McDonald, I., Alarcón, A., Fichtler, E., Licona, J.C., Pena-Claros, M., Sterck, F.J., Villegas, Z., Sass-Klaassen, U., 2010. The importance of wood traits and hydraulic conductance for the performance and life history strategies of 42 rainforest tree species. New Phytol. 185, 481-492.
Richard, M.B., Mendez, V.E., 2013. Interactions between carbon sequestration and shade tree diversity in a smallholder coffee cooperative in El Salvador. Conserv. Biol. 28, 489-497.

Robinson, D.T., Brown, D.G., Currie, W.S., 2009. Modeling carbon storage in highly fragmented and human-dominated landscapes: linking land-cover patterns and ecosystem models. Ecol. Model 220, 1325-1338.

Rice, R., 2008. Agricultural intensification within agroforestry: the case of coffee and wood products. Agric. Ecosyst. Environ. 128, 212-218.

Rist, L., Shanley, P., Sunderland, T., Sheil, D., Ndoyee, O., Liswanti, N., Tieguhong, J., 2012. The impacts of selective logging on non-timber forest products of livelihood importance. Forest Ecol. Manage. 268, 57-69.

Ruiz-Jaen, M.C., Potvin, C., 2011. Can we predict carbon stocks in tropical ecosystems from tree diversity? Comparing species and functional diversity in a plantation and a natural forest New Phytol. 189, 978-987.

Schroth, G., Fonseca, G.A.B., Harvey, C.A., Gascon, C., Vasconcelos, H.L., Izac, A.M.N., 2004. Agroforestry and Biodiversity Conservation in Tropical Landscapes. Island Press, Washington, pp. 524 pp.

Saranpaa, P., 2003. Wood density and growth. In: Barnett, J.R., Jeronimidis, G. (Eds.), Wood Quality and its Biological Basis. Blackwell Publishing \& CRC Press. Biological Sciences Series, pp. 87-117.

Silver, W., Ostertag, R., Lugo, A., 2000. The potential for carbon sequestration through reforestation of abandoned tropical agricultural and pasture lands. Res. Ecol. 8, 394-407.

Slik, J.W., Bernard, C.S., Breman, F.C., Vanb, M., Salim, A., 2008. Wood density as a conservation tool: quantification of disturbance and identification of conservation-priority areas in tropical forests. Conserv. Biol. 22, 1299-1308.

Spracklen, D.V., Righelato, R., 2014. Tropical montane forests are a larger than expected global carbon store. Biogeosciences 11, 2741-2754.

Stegen, J.C., Swenson, S.G., Valencia, R., Enquist, E.J., Thompson, E., 2009. Aboveground forest biomass is not consistently related to wood density in tropical forests. Global Ecol. Biogeogr. 1-9.

Strassburg, B.B.N., Kelly, A., Balmford Davies, R.G., Gibbs, H.K., Lovett, A., Miles, L., Orme, C.D.L., Price, J., Turner, R.K., Rodrigues, A.S.L., 2010. Global congruence of carbon storage and biodiversity in terrestrial ecosystems. Conserv. Lett. 3, 98-105.

Swenson, N.G., Enquist, B.J., 2007. Ecological and evolutionary determinants of a key plant functional trait: wood density and its community-wide variation across latitude and elevation. Am. J. Bot. 94, 451-459.

Tadesse, G., Zavaleta, E., Shennan, C., FitzSimmons, M., 2014a. Prospects for forestbased ecosystem services in forest-coffee mosaics as forest loss continues in southwestern Ethiopia. Appl. Geog. 50, 144-151.

Tadesse, G., Zavaleta, E., Shennan, C., 2014b. Coffee landscapes as refugia for native woody biodiversity as forest loss continues in southwest Ethiopia. Biol. Conserv. 169, 384-391.

Tscharntke, T., Klein, A.M., Kruess, A., Dewenter, I.S., Thies, K., 2005. Landscape perspectives on agricultural intensification and biodiversity-ecosystem service management. Ecol. Lett. 8, 857-874.

Tilman, D., 1999. The ecological consequences of changes in biodiversity: a search for general principles. Ecology 80, 1455-1474.

Vashum, K.T., Jayakumar, S., 2012. Methods to estimate above-ground biomass and carbon stock in natural forests-a review. J. Ecosyst. Ecogr. 2, 116.

van Noordwijk, M., Rahayu, S., Hairiah, K., Wulan, Y.C., Farida, A., Verbist, B., 2002. Carbon stock assessment for a forest to coffee conversion landscape in SumberJaya (Lampung, Indonesia): from allometric equations to land use change analysis. Sci. China Life Sci. 45, 75-86 Suppl. Science in China Press Beijing.

Verchot, L.V., Van Noordwijk, M., Kandji, S., Tomich, T., Ong, C., Albrecht, A. Mackensen, J., Bantilan, C., Anumpama, K.V., Palm, C., 2007. Climate change: linking adaptation and mitigation through agroforestry. Mitig. Adapt. Strategies Glob. Chang. 12, 901-918.

Walker, J.C.F., 1993. Primary Wood Processing: Principles and Practice. Chapman and Hall, Oxford.

Wiersum, K.F., Gole, T.W., Gatzweiler, F., Vokmann, J., Bognette, J., Wirtu, O., 2008. Certification of wild coffee in Ethiopia: experiences and challenges. Forests Trees Livelihoods 18, 9-21.

Zhang, Y., Chen, H.Y.H., Reich, P.B., 2012. Forest productivity increases with evenness, species richness and trait variation: a global meta-analysis. J. Ecol. $100,742-749$.

Zomer, R.J., Trabucco, A., Coe, R., Place, F., 2009. Trees on Farm: Analysis of Global Extent and Geographical Patterns of Agroforestry. ICRAF Working Paper no . 89. World Agroforestry Centre, Nairobi Kenya. 